\title{
LAND RESOURCE MANAGEMENT STRATEGY FOR THE SUSTAINABILITY OF THE UPPER WATERSHED OF PALU (Case Study of Miu Sub Watershed in Sigi Regency)
}

\author{
${ }^{1)}$ Danang Widjajanto, ${ }^{1)}$ Uswah Hasanah \\ ${ }^{1)}$ Agriculture Faculty-Tadulako University, E-mail : d_widjajanto@yahoo.co.id, uswahmughni@yahoo.co.id
}

\begin{abstract}
Population growth and regional expansion has increased land needs for settlement, agriculture, and trade in the Palu watershed causing much pressure on the upper part of the watershed where Miu watershed is situated The general aim of the research was to generate strategy for sustainable land resources management in the Miu watershed as a buffer zone of the Lore-Lindu National Park. The objective of the research were 1) to predict soil erosion and sedimentation, 2) to analyze the feasibility of dominant farming systems, 3) to analyze rural development, and 4) to analyze community preference on land use priority. The erosion and sedimentation, and feasibility research was conducted through soil survey and socio-economic approach. The rural development index was determined using secondary data taken from related institution such as demography, regional structure and infra structure, and industrial-trade condition. The preferential analysis of land use priority for 10 years ahead was done using focus group discussion with farmer community leaders. The soil erosion rate was light - heavy whilst the soil erosion index was low - very high estimated by the USLE. The relationship between the river debit and suspended load at the upper and lower part of the watershed was found to follow the equation of $Y=0.001 X^{1.366}\left(R^{2}=0.65\right)$, and $Y=0.001 X^{1.409}\left(R^{2}=0.66\right)$, respectively. Three villages included Pakuli, Pandere, and Bolapapu had high index of rural development whereas low index was found in Lonca, Bangga and Tangkulowi. The high-low order of land use priority was agro forestry, cacao monoculture, fresh water fishery, wetland rice, ruminant grazing, mixed culture of rice, soy bean, cassava and maize, and poultry farming.
\end{abstract}

Keywords: Buffer zone, Erosion, Land use, Watershed management, The Lore-Lindu National Park.

\section{INTRODUCTION}

Palu watershed is one of the super priority watersheds in Indonesia. The utilization of this region for providing resources such as land, food, water, energy, esthetics, and germplasm is considerably important for the people in Palu valley. Population growth rate of $2.7 \%$ year $^{-1}$ (BPS, 2009) and regional expansion has increased land needs for settlement, agriculture, and trade in lower part of Palu watershed. This situation has put much pressure on the upper part of the watershed where Miu watershed is situated.
The watershed of Miu covers an area of about 65,000 ha and has an important role as a buffer zone for the LoreLindu National Park. Forest conversion into cacao plantation in the last three decades has caused wide land degradation in this area as indicated by highly differences in river debit flows between dry and rainy seasons (LESATI, 2010). The use of conventional cultivation technology for establishing the cacao plantation and maize/cassava has lead to high soil erosion. Long term soil damage will decrease farmer's income due to low cacao and maize/cassava production and change the 
land suitability index for cacao and maize/cassava if soil erosion continues at present rates (Widjajanto, 2006).

To overcome the complexity of the land degradation problems existed and prevent further damage to the Miu watershed, one watershed one strategy approach that could integrate socioeconomic aspects and environmental physical aspects is in need. Integrated watershed management can sustain the development and management of natural resources as its implementation involve different environmental frameworks, strategies and policies could have positives impact on the watershed (Alemu, 2016).

The necessity for implementing the right strategy for the Miu watershed is to prevent ineffectiveness in the process of development. The general aim of the research was to generate strategy for sustainable land resources management in the Miu watershed. The objectives of the research were: 1 ) to predict soil erosion and sedimentation 2) to analyze the feasibility of dominant farming system, 3) to analyze rural development index, and 4) to analyze community preference on land use priority to support conservation farming system activities.

\section{MATERIALS AND METHODS}

Research Site. The Miu watershed is located in Sigi Regency of Central Sulawesi. It covers three sub districts: Gumbasa, South Dolo, and Kulawi.

\section{Hydrological Condition and Soil Erosion .} River debit and suspended load was observed in the main river of the Miu watershed. The relationship between the river debit and the suspended load was analyzed using regression technique. Soil erosion data was collected through survey and soil physico-chemical characteristic analysis. Locations for soil samples were determined using a stratified random sampling technique. The stratification was based on land units determining by overlaying various maps included land use, topography, and rainfall distribution maps. The soil samples within 32 land units (Figure 1) then were randomly taken. Recorded Rainfall data for the last 10 years covered the area of Kulawi, Gumbasa and South Dolo was obtained from the Provincial Office of Settlement and Infrastructure. Soil loss was predicted using the Universal Soil Loss Equation (Wischmeier and Smith, 1978). Tolerable soil loss and erosion hazard index were determined following the equation of Hammer (1980).

Farming System. Farming system data was purposively taken based on agro-ecosystem, and predominant cacao, wetland rice, maize and cassava areas. These areas included Pakuli, Tuwa, and Bolapapu villages. The number of respondents used was $10 \%$ of the total number of farmers who grow cacao, irrigated rice, corn and cassava. To determine the financial feasibility of the farming system, R/C technical analysis was employed in which $\mathrm{R}$ is income and $\mathrm{C}$ is production cost. The farming system was considered feasible when the $\mathrm{R} / \mathrm{C}$ is larger than 1.

Rural Development. Data of demography, village and cultivated land area size, structure and infrastructure, distance from sub district office were taken from Central Statistic Bureau (BPS, 2009). Scalogram method was used to analyze the rural development of Kulawi, Gumbasa and South Dolo sub district.

\section{Community Preference on Land Use}

Priority. Focus group discussion (FGD) with the leaders of the farmer groups in the Miu watershed guided with structure questionnaires was conducted for gathering community preferential data on the priority land use. The data were grouped into various aspects such as ecology (land Suitability, erosion hazard, and water availability), social (agricultural extension, cultivation practices, household need, and group collaboration) and economy (capital, 
market access, production price stability, financial profit, agricultural production equipment availability). The community selection on land use was found through deep interview with the farmer group respondents. Exponential Comparison method was employed to determine the priority scale on land use type developed in the Miu watershed. Land use types generally practiced in the research area are wetland rice, forest, agroforestry, monoculture maize and cassava, monoculture cacao, ruminants grazing, poultry farming and fresh water fishery.

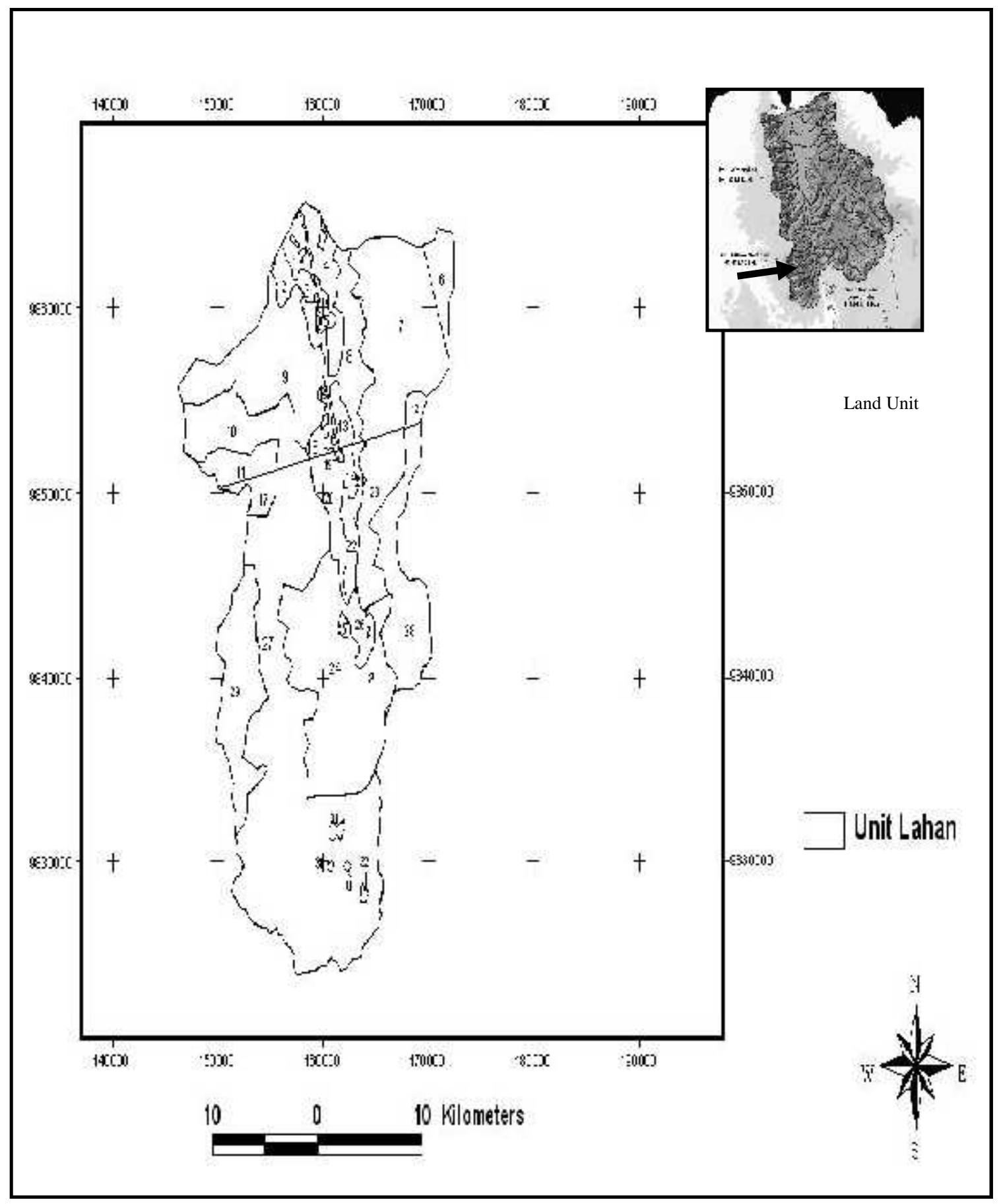

Figure 1. Land Unit Map of the Miu watershed 


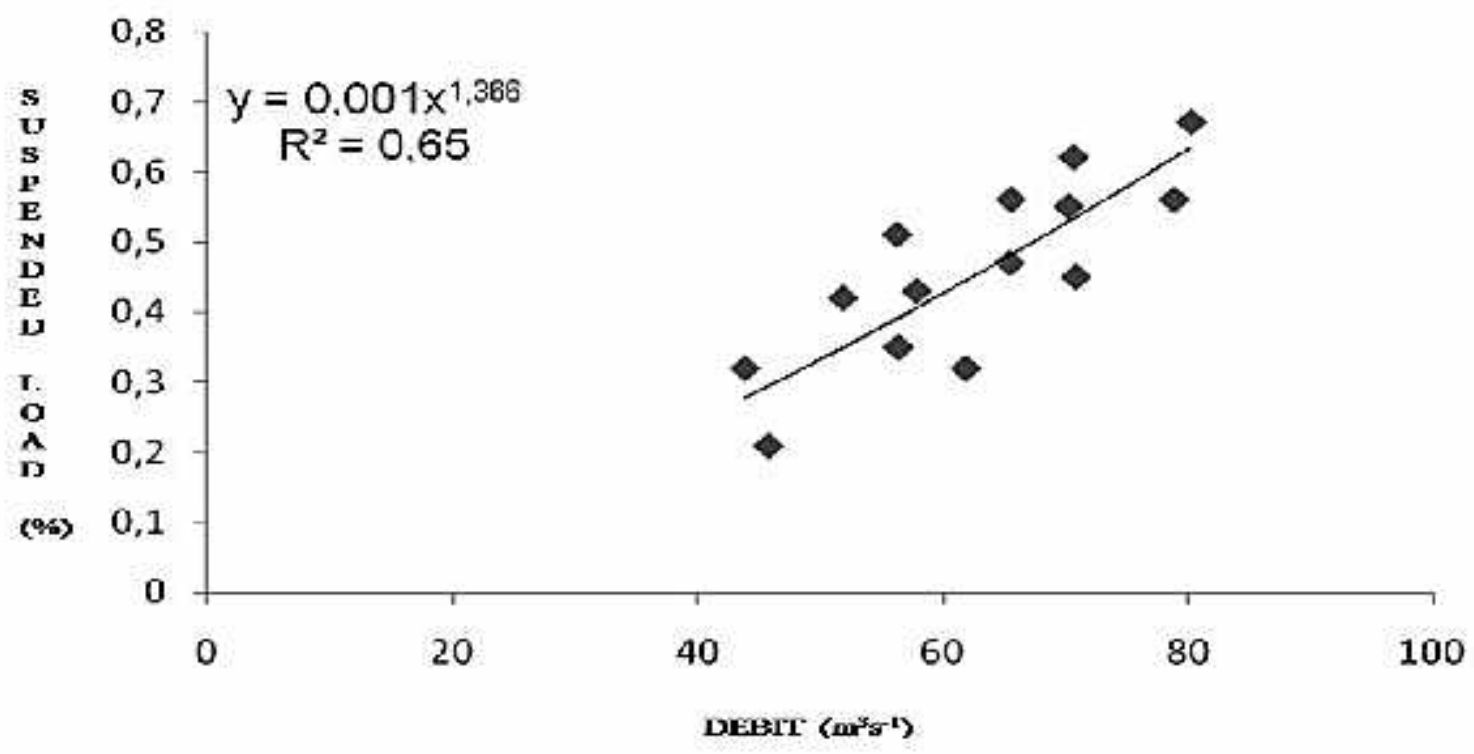

Figure 2. Suspended Load and River Debit Relationship in the Upper Miu Watershed

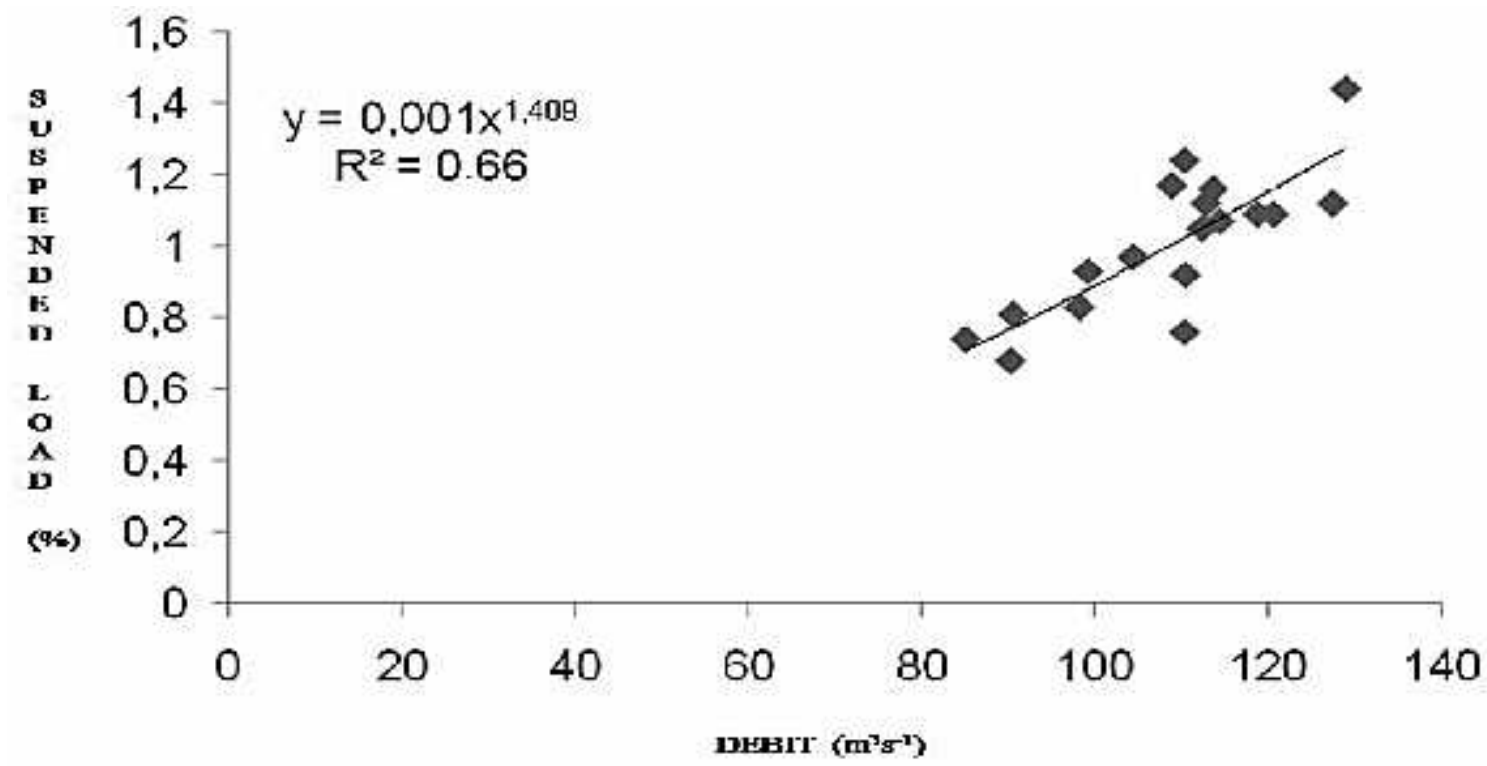

Figure 3. Suspended Load and River Debit Relationship in the Lower Miu Watershed.

\section{RESULTS AND DISCUSSION}

Hydrological Condition and Soil Erosion. The highest suspended load of the main river in the upper Miu watershed reached $0.7 \%$ at debit flow of about $80 \mathrm{~m}^{3} \mathrm{~s}^{-1}$ based on the equation : $\mathrm{Y}=0.001 \mathrm{X}^{1.366}\left(\mathrm{R}^{2}=0.65\right)$ where $\mathrm{Y}$ is the suspended load and $\mathrm{X}$ is debit. The suspended load at the lower Miu watershed was larger than that in the upper part $(1.6 \%)$ at river debit of $135 \mathrm{~m}^{3} \mathrm{~s}^{-1}$ based on the equation: $\mathrm{Y}=0.001 \mathrm{X}^{1.409}\left(\mathrm{R}^{2}=\right.$ 0.66 ) where $\mathrm{Y}$ is the suspended load and $\mathrm{X}$ is debit. The relationship between the suspended load and river debit in both parts of the Miu watershed is depicted in Figure 2 and 3.

Soil erosion in the Miu watershed ranges from light to heavy with Erosion Hazard Index (EHI) from low to very high as shown in Table 1. 
Table 1. Actual Soil Erosion Prediction in the Miu watershed.

\begin{tabular}{|c|c|c|c|c|}
\hline Land Unit & Land Use & $\begin{array}{c}\text { Soil Erosion } \\
\left(\mathrm{t} \mathrm{ha}^{-1} \mathrm{yr}^{-1}\right)\end{array}$ & $\begin{array}{c}\text { TSL } \\
\left(\mathrm{t} \mathrm{ha}^{-1} \mathrm{yr}^{-1}\right)\end{array}$ & EHI \\
\hline 1 & Mixed farming & $1.25^{*}$ & 19.20 & $0.22^{\#}$ \\
\hline 2 & Imperata & $0.38^{*}$ & 21.45 & $0.88^{\#}$ \\
\hline 3 & Rainfed cultivation & $10.22^{* 2}$ & 24.70 & $0.59^{\#}$ \\
\hline 4 & Irrigated rice & $0.06^{*}$ & 16.20 & $0.39^{\#}$ \\
\hline 5 & Rainfed cultivation & $17.52^{* 2}$ & 22.43 & $1.12^{\# 2}$ \\
\hline 6 & Forest & $0.88^{*}$ & 14.76 & $11.92^{\# 4}$ \\
\hline 7 & Forest & $1.01^{*}$ & 17.81 & $11.19^{\# 4}$ \\
\hline 8 & Forest & $0.17^{*}$ & 19.37 & $1.72^{\# 3}$ \\
\hline 9 & Imperata & $2.55^{*}$ & 23.64 & $5.40^{\# 3}$ \\
\hline 10 & Forest & $1.35^{*}$ & 17.42 & $15.55^{\# 4}$ \\
\hline 11 & Forest & $3.13^{*}$ & 14.15 & $44.23^{\# 4}$ \\
\hline 12 & Forest & $1.90^{*}$ & 13.90 & $27.3^{\# 4}$ \\
\hline 13 & Mixed farming & $2.25^{*}$ & 19.50 & $0.39^{\#}$ \\
\hline 14 & Mixed farming & $2.80^{*}$ & 22.13 & $0.42^{\#}$ \\
\hline 15 & Rainfed cultivation & $33.51^{* 2}$ & 19.05 & $2.51^{\# 2}$ \\
\hline 16 & Rainfed cultivation & $10.73^{* 2}$ & 16.25 & $0.94^{\#}$ \\
\hline 17 & Forest & $3.81^{*}$ & 21.44 & $35.57^{\# 4}$ \\
\hline 18 & Forest & $0.02^{*}$ & 23.56 & $0.17^{\#}$ \\
\hline 19 & Rainfed cultivation & $11.75^{* *}$ & 21.12 & $0.79^{\#}$ \\
\hline 20 & Forest & $0.10^{*}$ & 18.43 & $1.13^{\# 2}$ \\
\hline 21 & Forest & $0.09^{*}$ & 19.20 & $0.22^{\#}$ \\
\hline 22 & Rainfed cultivation & $16.71^{* 2}$ & 21.45 & $0.88^{\#}$ \\
\hline 23 & Forest & $1.96^{*}$ & 24.70 & $0.59^{\#}$ \\
\hline 24 & Forest & $0.04^{*}$ & 16.20 & $0.39^{\#}$ \\
\hline 25 & Rainfed cultivation & $28.51^{* 2}$ & 22.43 & $1.12^{\# 2}$ \\
\hline 26 & Rainfed cultivation & $40.20^{* 2}$ & 14.76 & $11.92^{\# 4}$ \\
\hline 27 & Forest & $0.38^{*}$ & 17.81 & $11.19^{\# 4}$ \\
\hline 28 & Forest & $2.00^{*}$ & 19.37 & $1.72^{\# 3}$ \\
\hline 29 & Forest & $2.46^{*}$ & 23.64 & $5.40^{\# 3}$ \\
\hline $30^{*}$ & Rainfed cultivation & $92.41^{* 3}$ & 17.42 & $15.55^{\# 4}$ \\
\hline 31 & Rainfed cultivation & $104.31^{* 3}$ & 14.15 & $44.23^{\# 4}$ \\
\hline 32 & Rainfed cultivation & $125.46^{* 3}$ & 13.90 & $27.30^{\# 4}$ \\
\hline
\end{tabular}

TSL: Tolerable Soil Loss; EHI: Erosion Hazard Index; ${ }^{*}$ Light TSL; ${ }^{* 2}$ Moderate TSL; ${ }^{* 3}$ Heavy TSL; ${ }^{*}$ Low EHI; ${ }^{\# 2}$ Moderate EHI; ${ }^{\# 3}$ High EHI; ${ }^{\# 4}$ Very High EHI.

The high soil erosion at land units $15,25,26,30,31$, and 32 was strongly related to land slope and ineffectiveness of the rainfed cultivation in preventing soil erosion. The sparsely vegetative cover in this type of land use exposes soil surface to direct rainfall impact. Widjajanto (2006) stated that the application of individual terrace and ridged terrace with agro-forestry pattern could effectively reduce soil erosion and runoff.

The erosion hazard index in the land units of $5,6,7,8,9,10,11,12,15,17,20$, $23,25,26,27,28,29,30,31$, and 32 varied 
between moderate to very high. The hilly and mountainous topography of the lands lead to potentially high soil erosion in the upper part of the Miu watershed. Organic matter addition could improve the physicochemical condition of the soil. Makinde et al. (2007), Gilandeh et al. (2009), and Bouajila dan Gallali (2010) stated that organic matter along with inorganic fertilizer can increase crop farming system profit in tropical rainforest region. Increasing soil organic matter also improves soil aggregate stability leading (Sarker, et $a l ., 2018)$ to sustainable soil productivity. In general, high soil carbon organic under soil conservation program can improve soil erodibility and soil water content capacity, and reduce runoff compare to conventional soil management.

Farming System. The dominant farming systems in the Miu watershed are irrigated rice, cacao, maize, and cassava (Table 2). Cacao and rice are the superior commodities for Central Sulawesi development. The $\mathrm{R} / \mathrm{C}$ value larger than one indicates that the farming systems in the Miu watershed are financially feasible to be developed.

Mappatoba and Laapo (2001) suggested an alternative model for farming system development around forest vicinity in which food crop, estate crops and animal husbandry are integrated in one farming system. Technology transfer of livestock feed industry at household scale can also be applied to increase farmers' knowledge in utilizing agricultural waste. Cassava based cropping system might also be an option to be integrated to rain forest ecological zone (Makinde et al., 2007).
Rural Development Index. Based on scalogram analysis shown in Table 3 (attachment 1), high rural development index was found Pakuli and Pandere villages of Gumbasa sub district and Bolapapu village of Kulawi sub district. Bangga village of South Dolo sub district and Lonca and Tangkulowi villages of Kulawi sub district have low rural development index. The other villages were classified as moderate.

Population and number of industrial trade business are the components influencing the rural development index most. Other components include public structure, agriculture, and trade has lesser influence. However, the public interest to obtain a suitable agricultural land, accessibility, and the concentration of trade in the more developed regions are thought to trigger the onset of migration.

Rauf et al. (2010) stated that agricultural sector has not been able to draw investment from other sectors indicating that the sector has weak influence on regional economy growth. However, agricultural post harvest processing sector such as wood and other forest product industry encourages investment from other sector resulting in relatively high economy growth in most areas of Central Sulawesi.

Bangga, Lonca and Tangkulowi villages have low rural index development due to their large area size and distant from central sub district government. Accessibility improvement to public structure and infrastructure needs (transportation, irrigation network, market and electricity) could lead to increasing population growth through local migration.

Tabel 2. Revenue and Cost Ratio (R/C) of the Dominant Farming System in the Miu Watershed

\begin{tabular}{lccc}
\hline Farming System & \multicolumn{3}{c}{ Village } \\
\cline { 2 - 4 } & Pakuli & Tuwa & Bolapapu \\
\hline Irrigated Rice & 1.14 & 1.13 & 1.12 \\
Cacao & 2.17 & 2.03 & 2.23 \\
Maize & 1.19 & 1.21 & 1.18 \\
Cassava & 2.85 & 3.05 & 2.93 \\
\hline
\end{tabular}


Table 4. The Scoring of Community Preference Assessment on Land Use Priority in the Upper Miu Watershed

\begin{tabular}{lccccccccc}
\hline \multirow{2}{*}{ Criteria } & \multirow{2}{*}{ Weight } & \multicolumn{7}{c}{ Alternative Value of Land Use Priority } \\
\cline { 3 - 10 } & & A & B & C & D & E & F & G & H \\
\hline Land Use Suitability & 9 & 9 & 7 & 9 & 3 & 5 & 9 & 5 & 7 \\
Soil \& Water Conservation Effort & 9 & 5 & 9 & 9 & 5 & 7 & 3 & 5 & 9 \\
Water Availability & 7 & 9 & 5 & 9 & 9 & 5 & 5 & 7 & 9 \\
Agricultural Extension & 7 & 5 & 7 & 7 & 3 & 5 & 5 & 5 & 5 \\
Cultivation Practice & 5 & 5 & 3 & 5 & 7 & 9 & 5 & 5 & 5 \\
Household Need & 3 & 7 & 3 & 3 & 3 & 3 & 3 & 7 & 7 \\
Group Collaboration & 7 & 3 & 7 & 9 & 3 & 5 & 3 & 3 & 3 \\
Capital & 7 & 7 & 3 & 5 & 3 & 9 & 3 & 3 & 5 \\
Market Access & 9 & 5 & 7 & 7 & 7 & 9 & 7 & 5 & 7 \\
Production Price Stability & 7 & 7 & 5 & 7 & 5 & 7 & 5 & 5 & 7 \\
Financial Profit & 9 & 7 & 5 & 7 & 7 & 9 & 7 & 7 & 7 \\
Production Equipment Availability & 7 & 7 & 3 & 7 & 7 & 7 & 3 & 5 & 5 \\
\hline
\end{tabular}

A: Wetland Rice; B: Forest; C: Agroforestry; D: Monoculture Maize/Cassava; E: Monoculture Cacao; F: Ruminant Livestock Grazing; G: Poultry Farming; H: Fresh Water Fishery

Table 5. Priority Land Use Preference of the Upper Miu Watershed Community.

\begin{tabular}{lcc}
\hline Land Use Type & MCM Value & Priority Order \\
\hline Agroforestry & $867,604,718$ & 1 \\
Cacao monoculture & $823,687,262$ & 2 \\
Fresh water fishery & $443,002,622$ & 3 \\
Irrigated rice & $435,168,254$ & 4 \\
Forest & $398,727,014$ & 5 \\
Livestock grazing & $397,041,758$ & 6 \\
Maize and Cassava & $50,898,854$ & 7 \\
Poultry farming & $5,840,078$ & 8 \\
\hline
\end{tabular}

MCM: Exponential Comparison Method.

Community Preference on Land Use Priority. Table 4 depicts the scoring of the community preference on land use priority based on focus group discussion with the farmer groups on the upper Miu watershed.

Table 4 shows that ecology and economy aspects are generally the important and very important factors in influencing the community preference on agricultural land resources development in the next ten years while the social aspect is considered less important.

Such condition as hillymountainous, abundant water availability and financial farming system feasibility support lead to agro-forestry and cacao monoculture practices as mostly preferred farming systems by the community compared to irrigated wetland rice and fresh water fishery (Table 5). Ruminant grazing, maize and cassava, and poultry farming system were less preferred.

Golar (2007) stated that the agricultural and forestry development reliance upon the market economy has prompt the widespread of cacao plantation in the buffer zone of TNLLP. Widjajanto and Gailea (2008) supported that farming 
financial feasibility and physical environment condition plays a very important role in the development of cacaoforestry farming system in Buffer Zone of TNLLP. The development of tree culture such as Tectona grandis (teak), Switenia macrophylla (mahogany), and Palaquium sp (nantu) is prioritized in forest resources development in the Toranda watershed, the buffer zone in the western part of Buffer Zone of TNLLP.

High cost production for labor and agricultural production equipments in wetland rice cultivation largely reduce farming profit. This condition could be improved by financial support for the farmers to increase their farming system capital. Credit assistance for farmers could increase the productivity of crop cultivation in various region of Central Sulawesi (Yantu et al., 2009) and play an important role in increasing farm income (Kumar et al., 2017).

\section{CONCLUSIONS}

1. Soil erosion in the Miu watershed is classified as light to heavy with erosion index ranges from low to very high.

2. The relationship between river debit and suspended load in the upper watershed follows the equation $Y=0,001 X^{1.366}$ $\left(R^{2}=0.65\right)$, whereas in the lower watershed $Y=0,001 X^{1.409}\left(R^{2}=0.66\right)$.
3. Farming system included wetland rice, cacao, maize and cassava is financially feasible to be developed in the Miu watershed.

4. The highest rural development index is found in Pandere, and Bolapapu villages whereas the lowest in Bangga, Lonca dan Tangkulowi villages.

5. The order of land use priority preference from strong to weak are agroforestry, cacao monoculture, fresh water fish farming, wetland rice, forest, ruminants grazing, palawija monoculture, and poultry farming.

\section{RECOMMENDATIONS}

1. Soil and water conservation techniques in the form of individual terrace, ridged terrace, soil organic matter improvement, and agroforestry are the best strategy to combat and prevent soil erosion.

2. Improving accessibility to public structure and infrastructure along with industry initiation at household scale to deal with agricultural and forestry production should be the right alternative for supporting rural region development.

3. Agroforestry development in the form of cacao plantation combining with high economy value woods is the most effective strategy to support sustainable agricultural development.

\section{ACKNOWLEDGMENT}

We would like to thank the Head of Palu-Poso Watershed Management Office for the financial support in strenghtening community based forest and watershed management (SCBFWM) program making this activity possible.

\section{REFERENCES}

Alemu, M.M. 2016, Integrated Watershed Management and Sedimentation. Journal of Environmental Protection 7: 490-494.

Bouajila, A. \& Gallali, T., 2010. Land Use Effect on Soil and Particulate Organic Carbon, and Aggregate Stability in some Soils in Tunisia. African Journal of Agricultural Research. 5 (8): 764-774.

BPS, 2009. Kecamatan Kulawi Dalam Angka, Badan Pusat Statistik Kabupaten Donggala. 
Gilandeh, Y.A., Sharabiani, V.R. \& Khalilian, A., 2009. Effects of Tillage Methods on Soil Fragmentation in Loamy Clay Soils. Am. J. Agri \& Biol. Sci. 4 (2): 131-136.

Golar, 2007. Strategi adaptasi masyarakat Toro: Kajian Kelembagaan Lokal dalam Pengelolaan dan Pemanfaatan Hutan di Taman nasional Lore-Lindu. Dissertation. Bogor Agricultural University. Bogor.

Hammer, W.I., 1980. Soil Conservation Consultant Report Tech. Note No.7, Centre for Soil Research. Bogor.

Izakovicová, Z., Špulerová, J., \& Petrovic, F., 2018. Integrated Approach to Sustainable Land Use Management Environments 5 (37): 1.

Kumar, A., Mishra, A.K., Saroj. S. \& Joshi, P.K. 2017. Institutional versus non-institutional credit to agricultural households in India: Evidence on impact from a national farmers' survey. Economic Systems 41(3): 420-432.

LESATI, 2010, Baseline Kondisi biofisik dan Sosial-Ekonomi Di Sub Daerah Aliran Sungai Miu, Kabupaten sigi, Propinsi sulawesi Tengah, The Report of Collaboration Program of Strenghtening Community Based Forest and Watershed Management (SCBFWM).

Makinde, E.A., Saka, J.O. \& Makinde, J.O., 2007. Economic Evaluation of Soil Fertility Management Options on Cassava Based Cropping Systems in the Rain Forest Ecological Zone of South Western Nigeria, African Journal of Agricultural Research 2 (1): 7-13.

Mappatoba, M. \& Laapo, A., 2001. Usahatani Lahan Kering pada Desa Terpencil di Kecamatan Kulawi Kabupaten Donggala. J. Agroland 8 (2): 150-157.

Rauf, R.A., Daryanto, A., Mangkuprawiro, S. \& Priyarsono, D.S., 2010. Pengaruh Investasi Sektor Pertanian dan Industri pengolahan hasil pertanian Di provinsi Sulawesi Tengah'. $J$. Agroland 17(1): 63-69.

Sarker, T.C., Incerti, G., Spaccini, R., Piccolo, A., Mazzoleni, S, \& Bonanomi, G., 2018. Linking organic matter chemistry with soil aggregate stability: Insight from ${ }^{13} \mathrm{C}$ NMR spectroscopy. Soil Biology and Biochemistry 117:175-184.

Widjajanto, D. \& Gailea, R., 2008. Kajian Pengembangan Agroforestri untuk Pengelolaan Daerah Aliran Sungai Toranda, Kecamatan Palolo, Kabupaten Sigi, Propinsi Sulawesi Tengah. J. Agroland.15(4): 264-270.

Widjajanto, D., 2006. Model Penggunaan Lahan untuk Pengembangan Pertanian Berkelanjutan (Studi Kasus Daerah Aliran Sungai Gumbasa, Donggala). Dissertation. Bogor Agricultural University. Bogor.

Wischmeier, W.H. \& Smith, D.P., 1978. Predicting Rainfall Erosion Losses: A Guide to Conservation Planning. USDA Agric. Handbook No. 53.

Yantu, M.R.., Sisfahyuni, \& Ludin, 2009. Kekuatan Permintaan dan Penawaran Subsektor Tanaman bahan makanan Dalam perekonomian Wilayah Propinsi Sulawesi Tengah', $J$. Agroland 16 (3): 237-244. 
(Attachment 1.) Table 3. Rural Development Index in the Miu watershed Miu

\begin{tabular}{|c|c|c|c|c|c|c|c|c|c|c|c|c|c|c|}
\hline Village & $\begin{array}{c}\text { Area } \\
\text { Size } \\
\left(\mathrm{km}^{2}\right)\end{array}$ & Distance $^{-1}$ & $\begin{array}{l}\text { Population } \\
\text { (person) }\end{array}$ & $\begin{array}{l}\text { Population } \\
\text { Density } \\
\left(\text { Jiwa km }^{-2}\right)\end{array}$ & $\begin{array}{l}\text { Households } \\
\mathrm{km}^{-2}\end{array}$ & $\begin{array}{c}\text { Electricity } \\
\text { Consumers } \\
\mathrm{km}^{-2}\end{array}$ & $\begin{array}{c}\text { Rice } \\
\text { Field \& } \\
\text { Pond } \\
\text { Area } \\
\text { Size } \\
\mathrm{km}^{-2}\end{array}$ & $\begin{array}{c}\text { Shop \& } \\
\text { Kiosk } \\
\text { Number } \\
\mathrm{km}^{-2}\end{array}$ & $\begin{array}{c}\text { School } \\
\text { Number } \\
\mathrm{km}^{-2}\end{array}$ & $\begin{array}{c}\text { Places } \\
\text { of } \\
\text { Worship } \\
\text { Number } \\
\mathrm{km}^{-2}\end{array}$ & $\begin{array}{c}\text { Industry } \\
\text { business } \\
\text { Number } \\
\mathrm{km}^{-2}\end{array}$ & RDI & $\mathrm{RDI}_{\text {Corr }}$ & RSC \\
\hline Bangga $^{-}$ & 185.08 & 0.33 & 2,163 & 11 & 0.05 & 1.92 & 1.51 & 0.13 & 0.03 & 0.02 & 2.87 & 17.86 & 0.56 & 1,21 \\
\hline Walatana & 95.26 & 0.50 & 1,432 & 15 & 0.08 & 2.10 & 2.95 & 0.26 & 0.05 & 0.04 & 4.69 & 25.67 & 0.92 & 1,31 \\
\hline Bulubete & 72.44 & 1.00 & 1,593 & 21 & 0.17 & 2.42 & 0.00 & 0.51 & 0.07 & 0.06 & 8.79 & 34.02 & 1.31 & $2, \overline{0} 8$ \\
\hline Tuwa & 34.24 & 0.13 & 1,691 & 49 & 0.26 & 7.10 & 11.39 & 0.44 & 0.09 & 0.20 & 10.96 & 79.57 & 3.44 & $5, \overline{8} 1$ \\
\hline Omu & 49.18 & 0.17 & 2,053 & 41 & 0.18 & 6.14 & 10.04 & 0.22 & 0.04 & 0.16 & 7.84 & 65.79 & 2.80 & $5, \overline{7} 4$ \\
\hline Simoro & 14.27 & 0.25 & 796 & 55 & 0.28 & 8.48 & 20.04 & 0.49 & 0.14 & 0.28 & 16.05 & 101.01 & 4.44 & $3, \overline{53}$ \\
\hline Pakuli $^{*}$ & 30.85 & 0.00 & 4,159 & 134 & 0.36 & 14.94 & 30.47 & 1.39 & 0.29 & 0.26 & 24.32 & 206.03 & 9.35 & 38,88 \\
\hline Pandere ${ }^{*}$ & 29.10 & 0.25 & 2,497 & 85 & 0.21 & 11.07 & 18.01 & 0.34 & 0.10 & 0.21 & 15.11 & 130.30 & 5.81 & 14,50 \\
\hline Winatu & 94.13 & 0.06 & 1,398 & 15 & 0.11 & 2.72 & 0.69 & 0.15 & 0.02 & 0.06 & 2.53 & 21.34 & 0.72 & 1,00 \\
\hline Lonca $^{-}$ & 56.85 & 0.11 & 498 & 9 & 0.07 & 0.63 & 0.28 & 0.05 & 0.02 & 0.02 & 1.07 & 11.25 & 0.25 & $\overline{125}$ \\
\hline Sungku & 36.15 & 0.33 & 959 & 26 & 0.17 & 3.46 & 0.47 & 0.19 & 0.11 & 0.19 & 6.86 & 37.78 & 1.49 & 1,42 \\
\hline Boladangk & 45.89 & 1.00 & 650 & 14 & 0.09 & 1.63 & 0.22 & 0.09 & 0.04 & 0.07 & 5.30 & 22.44 & 0.77 & 501 \\
\hline Tangkulo & 108.59 & 0.33 & 396 & 4 & 0.04 & 0.48 & 0.07 & 0.05 & 0.01 & 0.02 & 0.98 & 5.98 & 0.00 & 0 \\
\hline Mataue & 14.83 & 1.00 & 462 & 31 & 0.27 & 3.57 & 0.88 & 0.20 & 0.13 & 0.07 & 8.71 & 45.83 & 1.86 & 859 \\
\hline Bolapapu* & 32.06 & 0.00 & 2,215 & 69 & 0.31 & 16.72 & 2.34 & 1.28 & 0.28 & 0.37 & 18.53 & 108.83 & 4.81 & 10,65 \\
\hline Namo & 56.39 & 0.50 & 1,317 & 23 & 0.14 & 3.32 & 0.44 & 0.41 & 0.05 & 0.05 & 6.33 & 34.24 & 1.32 & 1,73 \\
\hline Salua & 16.03 & 0.06 & 1,138 & 71 & 0.37 & 8.61 & 0.00 & 1.06 & 0.12 & 0.19 & 11.96 & 93.37 & 4.09 & $4, \overline{6} 5$ \\
\hline Total & & 6.02 & 25,417 & 673.00 & 3.16 & 95.31 & 99.80 & 7.26 & 1.59 & 2.27 & 1.30 & 1041.31 & & \\
\hline Mean & & 0.35 & 1,495 & 39.59 & 0.19 & 5.61 & 6.65 & 0.43 & 0.09 & 0.13 & 0.09 & 61.25 & & \\
\hline \multicolumn{2}{|c|}{ Deviation Standard } & 0.34 & $1,083.80$ & 34.39 & 0.11 & 4.91 & 9.41 & 0.42 & 0.08 & 0.11 & 0.07 & 21.39 & & \\
\hline \multicolumn{2}{|c|}{ Maximum Value } & 1.00 & 4,159 & 134 & 0.37 & 16.72 & 30.47 & 1.39 & 0.29 & 0.37 & 0.21 & 206.03 & & \\
\hline \multicolumn{2}{|c|}{ Minimum Value } & 0.00 & 396 & 4 & 0.04 & 0.48 & 0.00 & 0.05 & 0.01 & 0.02 & 0.01 & 5.98 & & \\
\hline
\end{tabular}

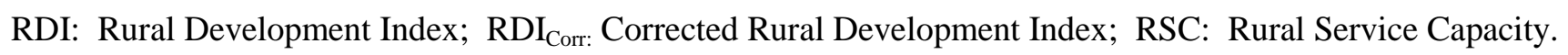

